\title{
Analisis Psikologi dan Sosiologi Korban Perang dalam Cerpen Sarajevo's Wombs And The Children Of Torns Karya Aiman Tashika
}

\author{
Heni \\ STIKOM UYELINDO KUPANG \\ heni5monika@gmail.com
}

\begin{abstract}
The most essential thing that every human in the world has is freedom. With freedom humans can display their existence as a result of reason and character. Freedom is a source of individual freedom to develop and develop their potential. But often humans are shackled by their freedom or independence by others. Likewise a nation that changes colonialism will be deprived of its freedom. The colonizing nation would oppose imposing its authority on its colonial state. The occupation of the Serbs against the Sarajevo nation was one of the cruel forms of colonialism on earth. Serbia commits terror against the citizens of Sarajevo. One form of horrific terror is the rapes committed by the Serbian army on Muslim women in Sarajevo. Serbia considers rape terror as the most effective weapon to kill the people of Sarajevo. The women of Sarajevo war victims recovered from the trauma that had escaped. Many of the victims of rape gave birth to children of Serbian soldiers. On the contrary, those who oppose the atrocities of the Serb-Sarajevo war are not only women but also innocent children as a result of rape. The psychological and sociological influence was very much accepted by the victims at the end of colonialism. Although the war is over, these victims of rape terror support life with unforgettable dark shadows. Both the mother and the child will continue to be haunted by these bad memories. These children would be difficult to accept in the community because they thought the children of the colonizers. They will be ostracized in the association and of course will resolve social discomfort.
\end{abstract}

Keywords: human, freedom, war, social changes, independence

\section{Pendahuluan}

Sastra menyajikan gambaran kehidupan, dan kehidupan itu sendiri sebagian besar terdiri dari kenyataan sosial. Dalam pengertian ini, kehidupan mencakup hubungan antar masyarakat dengan orang-orang, antar manusia, antar peristiwa yang terjadi dalam batin seseorang. Maka, memandang karya sastra sebagai penggambaran dunia dan kehidupan manusia, kriteria utama yang dikenakan pada karya sastra adalah "kebenaran" penggambaran, atau yang hendak digambarkan. Namun Wellek dan Warren mengingatkan, bahwa karya sastra memang mengekspresikan kehidupan, tetapi keliru kalau dianggap mengekspresikan selengkap-lengkapnya. Hal ini disebabkan fenomena kehidupan sosial yang terdapat dalam karya sastra tersebut kadang tidak disengaja dituliskan oleh pengarang, atau karena hakikat karya sastra itu sendiri yang tidak pernah langsung mengungkapkan fenomena sosial, tetapi secara tidak langsung, yang mungkin pengarangnya sendiri tidak tahu. Pengarang merupakan anggota yang hidup dan berhubungan dengan orang- orang yang berada disekitarnya, maka dalam proses penciptaan karya sastra seorang pengarang tidak terlepas dari pengaruh lingkungannya. Oleh karena itu, karya sastra yang lahir ditengah-tengah masyarakat merupakan hasil 
pengungkapan jiwa pengarang tentang kehidupan, peristiwa, serta pengalaman hidup yang telah dihayatinya. Dengan demikian, sebuah karya sastra tidak pernah berangkat dari kekosongan sosial. Artinya karya sastra ditulis berdasarkan kehidupan sosial masyarakat tertentu dan menceritakan kebudayaan-kebudayaan yang melatar belakanginya.(http://kajiansastra.blogspot.com/2009/04/sosiologisastra-sebagai pendekatan.html)

Hal paling hakiki yang dimiliki oleh tiap manusia di dunia adalah kebebasan. Dengan kebabasan tiap manusia dapat menunjukkan eksistensinya sebagai makhluk berasio dan berbudi pekerti. Kebebasan adalah sumber tiap individu untuk dapat berkarya dan mengembangkan potensi dirinya. Namun kerap kali manusia dibelenggu kebebasan atau kemerdekaannya oleh orang lain. Begitupun suatu bangsa yang mengalami penjajahan akan direnggut kebebasannya. Bangsa penjajah akan berusaha memaksakan otoritasnya terhadap negara jajahannya.

Penjajahan bangsa Serbia terhadap bangsa Sarajevo adalah salah satu bentuk kolonialisme yang kejam di muka bumi. Serbia melakukan teror terhadap warga Sarajevo. Salah satu bentuk teror yang mengerikan adalah perkosaan yang dilakukan tentara Serbia pada para wanita muslim Sarajevo. Serbia menganggap teror perkosaan adalah senjata paling ampuh untuk mematikan mental bangsa Sarajevo.

Perempuan-permpuan Sarajevo korban perang ini mengalami trauma yang mengerikan sepanjang hidupnya. Banyak dari korban perkosaan yang melahirkan anak- anak dari para tentara Serbia. Sebenarnya pihak yang mengalami dampak kekejaman perang Serbia- Sarajevo tidak hanya wanita- wanita tapi juga anak- anak tak berdosa hasil perkosaan. Pengaruh psikologis dan sosiologis sangat dirasakan para korban di masa berakhirnya kolonialisme. Meskipun perang telah usai, korbankorban teror perkosaan tersebut menjalani hidup dengan bayang- bayang kelam yang tak terlupakan sepajang hidup. Baik si ibu maupum si anak akan terus dihantui kenangan buruk tersebut. Anak - anak tadi akan sulit diterima dalam lingkungan masyarakat karena dinggap anak penjajah. Mereka akan dikucilkan dalam pergaulan dan tentu saja mengalami ketidakyamanan dalam bersosialisasi.

Dalam cerpen yang berjudul Sarajevo's Wombs and The Children of Torns, trauma memilukan akibat teror perkosaan dalam perang Serbia-Sarajevo dipaparkan dengan gamblang. Tokoh-tokoh dalam cepen mewakili penderitaan para wanita dan anak-anak korban penjajahan di Sarajevo. Dalam diri Mom, Esma, dan Edin kita bisa melihat betapa dahsyat dampak yang ditimbulkan peristiwa-peristiwa selama kolonialisme. Meskipun di cerpen ini dikisahkan tentang akibat-akibat traumatis kekerasan konflik di Sarajevo tapi ada hal-hal menarik dari sikap para tokoh dalam menyikapi trauma dalam dirinya.

\section{Metode Penelitian}

Penelitian ini menggunakan metode penelitian kualitatif dengan pendekatan postkolonial pada cerpen Sarajevo's Wombs And The Children Of Torns Karya Aiman Tashika. 
Jurnal Onoma: Pendidikan, Bahasa dan Sastra

ISSN 2443-3667 (print)

PBSI FKIP Universitas Cokroaminoto Palopo

ISSN 2715-4564 (online)

Volume 6 Nomor 1

Data dan sumber data:

Data primer pada penelitian ini adalah cerpen Sarajevo's Wombs And The Children Of Torns Karya Aiman Tashika. Data sekunder pada penelitian ini adalah buku-buku referensi yang mendukung analisis dalam penelitian dan yang dijadikan landasan teori dalam penelitian.

Pada analisis cerpen ini penulis menggunakan teori postkoloial yang dianggap sesuai untuk mengupas masalah-masalah dalam cerita. Teori postkolonial adalah suatu teori yang digunakan untuk menganalisis mengenai dampak psikologis dan sosiologis yang ditimbulkan oleh kolonialisme. Menurut Nyoman Kutha Ratna teori postkolonial bersifat multidisiplin yang melibatkan tiga pengertian, yaitu : a.) abad berakhirnya imperium koloial di seluruh dunia, b) segala tulisan yang berkaitan dengan pengalaman-pengalaman kolonial, c) teori-teori yang digunakan untuk menganalisis masalah-masalah pasca kolonial. (Ratna, 2005: 23)

Analisis wacana postkolonial bisa digunakan, di satu pihak untuk menelusuri aspek-aspek yang tersembunyi atau sengaja disembunyikan sehingga dapat diketahui bagaimana kekuasaan itu bekerja, di pihak lain membongkar disiplin, lembaga, dan ideologi yang mendasarinya (Ratna, 2008: 56)

Ciri penting lainnya adalah kenyataan bahwa secara definitif teori postkolonial dimanfaatkan untuk menganalisis khazanah kultural yang menceritakan peristiwaperistiwa yang terjadi di negara- negara pascakolonial (Ratna, 2005: 32). Nyoman Kutha Ratna juga berpendapat bahwa paling sedikit terkandung empat alasan mengapa karya sastra dianggap tepat untuk dianalisis melalui teori- teori postkolonial.

a. Sebagai gejala kultural, sastra menampilkan sistem komunikasi antara pengirim dan penerima, sebagai mediator antara masa lampau dengan masa sekarang.

b. Karya sastra menampilkan berbagai problematika kehidupan, emosonalitas, dan intelektualitas, fiksi dan fakta, karya sastra adalah masyarakat itu sendiri.

c. Karya sastra tidak terikat oleh ruang dan waktu, kontemporaritas adalah manifestasinya yang paling signifikan.

d. Berbagai masalah yang dimaksudkan dilukiskan secara simbolis, terselubung, sehingga tujuan- tujuan yang sesungguhnya tidak tampak.

\section{Pembahasan}

Dalam pembahasan ini akan dianalisis tentang dampak- dampak trauma psikologis dan sosiologis perang Serbia terhadap Sarajevo pada para wanita dan anak- anak yang dilahirkan dari teror perkosaan. Peristiwa-peristiwa yang terjadi selama perang menunjukkan kekejaman yang dilakukan para tentara Serbia terhadap warga Sarajevo, khususnya wanita- wanita muslim disana.Hal ini dapat kita lihat pada kutipan cerita berikut:

Data 1

....Menurut catatan- catatan yang kubaca, setidaknya ada 20 ribu perempuan muslim yang dizalimi. Ditengarai, bahwa yang melakukan perbuatan setan itu memang para tentara Serbia....(par 15) 
Jurnal Onoma: Pendidikan, Bahasa dan Sastra

ISSN 2443-3667 (print)

PBSI FKIP Universitas Cokroaminoto Palopo

Volume 6 Nomor 1

ISSN 2715-4564 (online)

Data 2

.....terdapat pula tentara- tentara yang mendatangi rumah- rumah wanita itu dalam keadaan mabuk, menjebol pintu, memukul, menyundut dengan puntung rokok menyala, melukai dengan pisau, menuntut mereka tersenyum di tengah penyiksaan tersebut dan diperkosa di depan suami- suami mereka. ( par 16)

Strategi perang yang digunakan Serbia dalam kaitannya maksud terselubung dalam teror perkosaan terhadap wanita- wanita Sarajevo yakni adanya maksud untuk memperbanyak ras Serbia di dunia.

Data 3

.....Mereka melakukannya untuk strategi berperang. Serbia menjadikan perkosaan massal sebagai senjata teror. (par 15)

Data 4

.....Perkosaan itu merupakan tindakan yang direncanakan. Para perempuan itu

diperkosa untuk melahirkan anak- anak Serbia. Akibatnya, diperkirakan ratusan sampai ribuan bayi terlahir dari perkosaan..... (par 17)

Peristiwa- peristiwa perang menjadi peristiwa masa lalu yang kelam bagi tokoh Mom dan Esma yang mempunyai sikap yang berbeda dalam menghadapi trauma dalam dirinya.Bagi Edin, anak kandung Esma dari hasil perkosaan, peristiwa yang terjadi di Sarajevo menjadi asal -usulnya lahir di dunia, yang menimbulkan dampak psikologis dan sosiologis dalam dirinya.

\section{A. Mom}

Dalam cerpen ini tokoh Mom digambarkan sebagai wanita yang kuat dan tangguh. Walaupun ia sebagai salah satu korban perkosaan ia tidak larut dalam kesedihan berkepanjangan. Sebaliknya, ia menjadi sosok yang tegar dan berusaha membantu para korban perkosaan yang lain. Mom berusaha mengubur trauma masa lalunya dalam kesibukannya sebagai aktivis dalam suatu organisasi kemanusiaan.

Data 5

Sudahkah aku ceritakan kalau mom adalah korban perkosaan tentara serbia juga?(par 13)

Data 6

Tapi ia termasuk yang langka. Dia bisa bertahan mski cerita buruk tidak hanya menimpanya, .... Sudah kubilangi ia wanita yang tangguh, bukan? Entah bagaimana ia melewati itu semua. Bahkan tidak hanya melewati, Mom sekarang juga menjadi relawan yang membantu para korban perkosaan melewati memori buruk yang Data 7 bergerak-gerak bersama album hidup merela. (par 14)

Tugas Mom memang seabrtek di organisasi barunya. Bukan ditugaskan, tapi inisiatif (par 35)

Ia menjadi sangat aktif dalam usahanya memberi dukungan pada para korban perkosaan. Mom berusaha menemukan kebahagiaan dan kepuasan batin dengan membantu mempertemukan ibu dan anak korban perkosaan. Data 8 
Jurnal Onoma: Pendidikan, Bahasa dan Sastra

Volume 6 Nomor 1

Esma adalah kasus kedua. Sebelumnya, ia telah berhasil mempersatukan seorang wanita bernama Safeta dan anaknya, Seada. Mom sangat puas dan mencari kehangatan yang sama di dadanya pada kasus- kasus yang lain.(par 36)

Dalam membesarkan dan merawat Edin, Mom melakukannya dengan sepenuh hati. Ia benar- benar menyayangi Edin seperti anak kandungnya sendiri. Ia selalu memberi dukungan dan membesarkan hati Edin saai si anak merasa sangat terpukul saat tahu bahwa ia adalah anak dari perkosaan tentara Serbia.

Data 9

Mom bilang, kalau kamu bukan anak kandung Mom, lalu kenapa ? Mom menyayangimu. Mom rela mengorbankan nyawa demimu. Tidakkah itu cukup membuatmu berhenti bersedih ? (par 7)

Tampaknya Mom sebagai wanita korban perkosaan dapat melewati trauma dalam hidupnya dengan sangat baik. Secara psikologis ia menjadi wanita yang tegar dan tangguh dan berusaha mencari pengobatan bagi traumanya dengan menolong korban- korban lainnya. Secara sosiologis, Mom makin giat dalam kegiatan organisasi. Mom dapat bersosialisasi dengan baik dan membaktikan dirinya untuk kepentingan kemanusiaan.

\section{B. Esma}

Esma adalah ibu kandung Edin. Sebagai salah satu korban perkosaan, sikap Esma sangat bertolak belakang dengan Mom yang juga sama- sama korban teror tersebut. Esma menjadi wanita yang sangat larut dalam kesedihan, merasa selalu dibayangi masa lalunya yang kelam, sehingga ia mengalami depresi berat. Ia bertahun- tahun mengurung diri dalam kamar dan mengasingkan dirinya dari kehidupan luar.

Data 10

.....Dia tampak tua. Aneh- padahal tadi aku mendengar ini hari ulang tahunnya yang ke-39.......dia seperti tidak terurus - atau tidak mau diurus. Nampak tidak ramah pada semua orang (par 30)

Saat Mom berusaha untuk menolongnya, Esma menjadi sangat marah. Ia tidak mau lukanya dikorek- korek lagi .Ia selama ini berusaha menyingkir dari kehidupan di masyarakat untuk melupakan traumanya, tapi nampaknya sama sekali tidak berhasil . Esma malah makin hanyut dalam penderitannya.

Data 11

........sudah belasan tahun berelalu tanpa kesembuhan..........(par 28)

........kau mengingatkannku lagi padanya, perempuan tua. Apa salahku?! Tidak bisakah kalian membiarkanku hidup tenang? Tidak bisakah kalian melihatku bahagia?....apa mau kalian? Kalian sama saja dengan setan- setan itu. Kalian setan (par32)

Ia merasa bahwa hanya ia yang menjadi korban, sehingga melupakan anak yang ia lahirkan dan berusaha ia lupakan. Ia sama sekali tidak ingin bertemu dengan anak tersebut, karena hanya akan makin mengingatkan pada peristiwa masa lalunya. Disini dampak psikologis sangat terasa pada diri Esma. Akibat dari kolonialisme , yakni teror perkosaan sangat mengguncang pribadi Esma. Dampak perang tersebut telah membawa Esma pada jurang kehancuran. Peristiwa- peristiwa selama perang 
Jurnal Onoma: Pendidikan, Bahasa dan Sastra

yang terjadi di masa lalu Esma sangat mempengaruhi kepribadian dan kejiwaan Esma pada masa kini.

Data 12

....Mom dan aku tengah menuju rumah salah seorang muslimah korban kebiadaban orang- orang Serbia. Dunia boleh jadi telah melupakannya, tapi disini, kami tidak Data 13 punya pilihan selain hidup dalam bayang- bayang kelamnya.(par 11)

Tahun- tahun yang dikenang sebagai pelanggaran kemanusiaan terburuk di Eropa pasca perang Dunia II itu masih berbekas di hari- hari kami. .....Bukan haya fisik yang cedera, namun mental seperti dicabut, ditarik kasar keluar dari kewarasan.....(par 12)

Dampak sosiologis pada diri Esma akibat peristiwa- peristiwa yang terjadi di masa perang membuat ia mengasingkan diri dari lingkungan masyarakat. Ia tidak mau bersosialisasi dengan orang lain dan hanya mengurung diri di kamar selama belasan tahun. Mungkin dalam diri Esma ada perasaan malu dan ternoda, sehingga ia menutup diri dari pergaulan.

\section{Edin}

Sebagai anak hasil perkosaan, Edin tumbuh sebagai anak yang bersemangat dan ceria karena dibesarkan dengan penuh perhatian dan kasih sayang dari Mom. Semangat dalam diri Mom tertular pada Edin yang juga senang membantu kesusahan orang lain.

Data 14

"kapan kita menjenguknya? aku tidak sabar ingin menyemangatinya. "( par 38)

Pada saat Edin mengetahui bahwa ia bukan anak kandung Mom dan sebenarnya ia adalah anak korban perkosaan tentara Serbia, ia sangat marah dan terpukul. Tapi berkat kesabaran dan dukungan dari Mom, lambat laun ia dapat menerima keadaan dirinya.

Tentu saja Edin mengalami masalah psikologis dan sosiologis akibat dari peristiwa perang, meskipun ia tidak secara langsung mengalami teror perkosaan, tapi ia adalah hasil dari teror tersebut, yang awalnya tidak mengetahui dari mana ia sebenarnya. Saat ia tahu siapa ia sebenarnya, secara psikologis Edin terguncang dan marah.

Data 15

....Aku menjerit, menangis, menunjuk- nunjuk perutnya sambil berkata, " Mengapa Mom membohongi aku? Mom bilang Mom membawaku ke dunia ini dari sana !( par 5)

Sebagai anak yang tidak mengetahui siapa orang tuanya, dalam diri Edin ada keinginan untuk mencari identitas dirinya. Ada keinginan pada Edin untuk bertemu dengan ibu dan ayahnya, meski ia tahu ayahnya adalah tentara Serbia yang dibencinya.

Data 16

...Aku sadar aku terganggu. Mungkin sesungguhnya aku benar- benar ingin tahu asalusulku. Aku ingin lihat wajah ibu kandungku. Aku ingin tahu ayahku- lalu meludahinya, memakinya, atau mungkin memeluknya.( par 10) 
Jurnal Onoma: Pendidikan, Bahasa dan Sastra

ISSN 2443-3667 (print)

PBSI FKIP Universitas Cokroaminoto Palopo

Volume 6 Nomor 1

ISSN 2715-4564 (online)

Data 17

Namun ketika aku mencoba jujur pada diri sendiri, aku mendapati pernyataan yang mencengangkan keluar dari dalam jiwaku. Kau tidak melakukan ini semata untuk Mom, katanya. Kau melakukan ini untuk sesuatu yang lain. Sesuatu yang mengganjal perasaanmu sejak lama.( par 9)

Edin marah pada ibu kandungnya yang telah meninggalkannya begitu saja. Ia menganggapnya sebagai wanita egois yang merasa hanya dia saja yang menjadi korban dan menderita. Padahal sebagai anak ia memerlukan dukungan dari ibu kandungnya untuk menghadapi masalah- masalahnya di masyarakat. Edin kecewa dengan ibu kandungnya yang hanya mementingkan diri sendiri dan lari dari kenyataan.

Data 18

Aku misalnya. Sebagai anak hasil perkosaan, dibuang saja sudah sangat menyakitkan. Apalagi menerima kenyataan bahwa orangtuaku, mungkin seperti wanita di dalam, tidak mau sembuh, tidak mau memperbaiki kesalahan, dan bersikeras itu bukan kesalahan. Bagaimana mungkin kau menganggap membuang bayi yang kau lahirkan adalah satu- satunya cara untuk sembuh dari trauma perkosaan? bukankah itu sama saja mengatakan bahwa berbuat dosa adalah jalan keluar dari hasil dosa orang lain? Bodoh, egois..... ( par 25)

Sebagai anak hasil perkosaan, Edin mengalami masalah sosiologis. Ia dianggap sebagai anak penjajah dan sering diejek teman- temannya. Ia tidak sepenuhnya diterima oleh masyarakat Sarajevo yang membenci orang Serbia karena penderitaan yang telah mereka terima selama perang. Edin dianggap tidak layak tinggal bersama di tengah kehidupan sosial masyarakat setempat.

Data 19

......Aku masih ingat ketika mereka, dengan mengejek, memanggilku "Pero", nama yang lazim dipakai orang Serbia. Mereka diberitahu, entah oleh siapa bahwa aku bukan anak Mom. Aku anak orang Serbia, bukan Sarajevo. Aku anak penjajah. Aku anak yang tidak diinginkan. Umurku masih 8 tahun waktu itu, - dan rasanya sakit. Di sini di dekat jantung. .....( par 5 )

Peristiwa perkosaan pada perang Serbia - Sarajevo mengakibatkan kehidupan sosial Edin menjadi tidak nyaman, karena ia dianggap anak Serbia. Dari sini kita lihat betapa besar dampak perang pada Edin secara psikologis dalam dirinya dan secara sosiologis di masyarakatnya. Ia tidak diakui sebagai orang Sarajevo, padahal ia juga tidak menginginkan lahir sebagai orang Serbia, apalagi hasil perkosaan yang biadab. 
Jurnal Onoma: Pendidikan, Bahasa dan Sastra

\section{Simpulan}

Dari pembahasan di atas dapat kita lihat betapa mengerikan dampak yang diakibatkan perang terhadap kehidupan orang- orang yang terjajah., meski perang telah selesai. Trauma kejiwaan dan masalah- masalah sosial akan tetap dirasakan para korban seumur hidup mereka. Terlebih trauma itu bersumber dari suatu kekejaman yang disebut teror perkosaan. Dampaknya pada seorang wanita akan sangat menyakitkan. Begitulah perasaan para wanita Sarajevo korban perkosaan. Mereka akan terus menanggung malu, rasa hina pada diri sendiri, dan akan terus dihantui kenangan mengerikan tersebut seumur hidup.

Gambaran sosok Mom, Esma, dan Edin adalah sosok- sosok tak berdosa yang harus menanggung penderitaan sepanujang umur mereka. Bagaimanapun, perang tidak akan pernah membawa kebaikan, hanya akan mengkoyak perdamaian dan sendi- sendi kehidupan suatu bangsa. Tentu saja yang paling merasakan dampak perang atau suatu penjajahan adalah rakyat. Peristiwa- peristiwa tragis yang terjadi selama penjajahan akan selalu melekat dan berimbas pada hidup mereka. Baik itu segi psikologis, sosiologis, ekonomi, budaya, dan yang lainnya. Sastra sebagai bagian dari kehidupan suatu bangsa akan sangat berperan dalam memaparkan dan membedah masalah- masalah akibat kolonialisme tersebut. 
Jurnal Onoma: Pendidikan, Bahasa dan Sastra

ISSN 2443-3667 (print)

PBSI FKIP Universitas Cokroaminoto Palopo

Volume 6 Nomor 1

ISSN 2715-4564 (online)

\section{Daftar Pustaka}

Kutha Ratna, Nyoman. 2005. Sastra dan Cultural Studies : Representasi Fiksi dan Fakta. Yogyakarta : Pustaka Belajar

Kutha Ratna, Nyoman. 2008. Postkolonial dalam Relevansi Sastra. Yogyakarta : Pustaka Belajar

Tashika, Aiman, Sarajevo Wombs and The Children of Torns, 1999

http://kajiansastra.blogspot.com/2009/04/sosiologi-sastra-sebagai-pendekatan.html 